\section{KIR HAPLOTYPE CAN INFORM DONOR SELECTION PRODUCTION OF ALLOGENEIC MEMORY-LIKE CAR NK CELLS FOR CLINICAL APPLICATION}

Hadia Lemar*, Anmol Vohra, Ming-Hong Xie, Ivan Chan, Sasha Lazetic, James Trager. NKarta Therapeutics, South San Francisco, CA, USA

Background NK cells expanded on membrane-bound (mb) IL15 and 41BBL expressing K562 stimulatory cells (NKSTIM) for clinical use can be genetically modified to express activating chimeric receptors. ${ }^{1}{ }^{2}{ }^{3} \mathrm{NK}$ cells activated in the presence of IL-12, IL-15 and IL-18 develop cytokine induced memorylike (CIML) phenotype and function; these cells have shown clinical promise. ${ }^{4}$ Additionally, HSCT AML transplants using NK KIR Haplotype Group B donors with better and best Group B profiles ( $\geq 2$ activating genes) show better survival. ${ }^{5}$ 6 Here we investigate whether KIR profiles impact healthy allogeneic donor NK cell function and phenotype when these cells are expanded on NKSTIM in the presence of IL-12 and IL-18 (12-18).

Methods Healthy donor PBMC NK were genotyped for HLA and KIR and expanded on K562-mbIL15-41BBL stimulatory cells with IL-2 alone or with IL-2 plus IL-12 and IL-18 (1218). Expanded NK were transduced with CAR constructs including CD19, and then evaluated for NK cell expansion, cytokine secretion, RNA profiles, cytotoxicity against tumor lines, and cell surface phenotypes. Expanded CD19 NK donors with varying numbers of activating KIR vs inhibitory KIR were tested for effector function, and these donors were then tested for in vivo efficacy and pharmacokinetics. A KIR ranking score was developed by considering both the number of activating and inhibitory KIR genes expressed by each donor. This score was correlated with functional properties of CAR NK cells.

Results Addition of $12-18$ to the K562-mbIL15-41BBL stimulatory cells improves CD19-CAR NK potency 2-fold relative to the stimulatory cell line alone $(\mathrm{P}=.02)$ while $\mathrm{NK}$ cell expansion is unchanged. $12-18$ also drove an increase in effector cytokine accumulation on exposure of CAR-NK to CD19 tumor. CIML CAR NK cells from donors with higher KIR scoring also had higher cytotoxicity (Pearson's $\mathrm{R}=0.74$, $\mathrm{P}=0.006)$; this correlation was not observed following expansion in the absence of $12-18$. 12-18 also drove more potent in vivo activity against tumor with an increased presence of circulating NK cells over 4 weeks in the mice.

Conclusions CIML CAR NK cells derived from donors with favorable KIR scoring have greater cytotoxic activity, effector cytokine production, and in vivo pharmacokinetics and efficacy. These findings may provide an important criterion for donor selection in the development of more robust and potent engineered NK cells for clinical use.

\section{REFERENCES}

1. Lapteva N, Durett AG, Sun J, Rollins LA, Huye LL, Fang J, Dandekar V, Mei Z, Jackson K, Vera J, Ando J, Ngo MC, Coustan-Smith E, Campana D, Szmania S, Garg T, Moreno-Bost A, Vanrhee F, Gee AP, Rooney CM. Large-scale ex vivo expansion and characterization of natural killer cells for clinical applications. Cytotherapy 2012;14(9):1131-1143.

2. Chihaya I, Iwamoto S, Campana D. Genetic modification of primary natural killer cells overcomes inhibitory signals and induces specific killing of leukemic cells. Blood 2005; 106:376-383.

3. Yang Y, Connolly J, Shimasaki N, Mimura K, Kono K, Campana D. A Chimeric Receptor with NKG2D Specificity Enhances Natural Killer Cell Activation and Killing of Tumor Cells. Cancer Res 2013;73(6):1777-1786.

4. Romee $R$, Rosario $M$, Berrien-Elliott MM, Wagner JA, Jewell BA, Schappe $T$, Leong JW, Abdel-Latif S, Schneider SE, Willey S, Neal CC, Yu L, Oh ST, Lee YS, Mulder A, Claas F, Cooper MA, Fehniger TA. Cytokine-induced memory-like natural killer cells exhibit enhanced responses against myeloid leukemia. Sci Trans Med 2016;8(357): 357ra123.

5. Cooley S, Weisdorf DJ, Guethlein LA, Klein JP, Wang T, Le CT, Marsh SGE, Geraghty D, Spellman S, Haagenson MD, Ladner M, Trachtenberg E, Parham $\mathrm{P}$, and Miller JS. Donor selection for natural killer cell receptor genes leads to superior survival after unrelated transplantation for acute myelogenous leukemia. Blood 2010;116(14):2414-2419.

6. Cooley S, Weisdorf DJ, Guethlein LA, Klein JP, Wang T, Marsh SGE, Spellman S, Haagenson MD, Saeturn K, Ladner M, Trachtenberg E, Parham P, and Miller JS. Donor Killer Cell Ig-like Receptor B Haplotypes, Recipient HLA-C1, and HLA-C Mismatch Enhance the Clinical Benefit of Unrelated Transplantation for Acute Myelogenous Leukemia. JI, 2014;192(10):4592-600.

Ethics Approval Animal studies were conducted with IACUC approval.

http://dx.doi.org/10.1136/jitc-2021-SITC2021.128 